\title{
Identifikasi Kendala Relawan Demokrasi Basis Perempuan sebagai Fasilitator Pendidikan Pemilih di Kota Pekanbaru dan Kota Dumai
}

\author{
Hariyanti' ${ }^{1}$ Hambali \\ Prodi Pendidikan Pancasila dan Kewarganegaraan, Fakultas Keguruan dan Ilmu Pendidikan, \\ Universitas Riau, Indonesia \\ 1hariyanti@lecturer.unri.ac.id
}

\begin{abstract}
This study aims to describe the obstacles faced by Democracy Volunteers, a social movement partnering the General Election Commission (KPU) in improving voters' education in the 2019 simultaneous regional election in the cities of Pekanbaru and Dumai, Riau province. Democracy Volunteer has the principle "from voters to voters", because as facilitators, they come from the community that they will educate. This research used a qualitative approach with descriptive method. Informants were determined through non-probability sampling technique using purposive sampling technique. The number of research informants amounted to nine people consisting of the KPU commissioners and staff in charge of the Democracy Volunteer program, as well as Democracy Volunteers members for women voters. The data validity was tested using triangulation of data sources. The findings of the study show that in carrying out its duties as the facilitators of voter education, the Democracy Volunteers experience several obstacles, including (1) limited working time for volunteers; the allocated two-month time meant that not all regions could be visited to spread information on election and democracy; (2) limited time for the implementation of voter education activities in the community; (3) limited knowledge of Democracy Volunteers regarding electoral technicality and the lack of confidence in delivering material to the community so that only certain internal volunteers are relied on while others are only tasked with facilitating activities such as distributing snacks, installing banners and preparing attendance; (4) the apathy of the target community towards electoral information hence it is quite difficult to provide understanding and even motivation to participate in the election. Democracy Volunteers are partners of the KPU in inviting the public to become smart and responsible voters in order to accomplish quality elections.
\end{abstract}

Keywords: Democracy Volunteers, women voters, voter education

\section{ABSTRAK}

Penelitian ini bertujuan untuk mendeskripsikan kendala yang dihadapi Relawan Demokrasi, mitra Komisi Pemilihan Umum dalam meningkatkan pengetahuan pemilih dalam pemilu, pada pemilu serentak 2019 di Kota Pekanbaru dan Kota Dumai, terutama basis pemilih perempuan. Relawan Demokrasi mempunyai konsep "dari pemilih kepada pemilih", sebab sebagai fasilitator, mereka berasal dari komunitas yang akan diedukasinya. Penelitian ini menggunakan pendekatan kualitatif dengan metode deskriptif. Penentuan informan penelitian melalui teknik non-probability sampling dengan teknik purposive sampling. Informan penelitian berjumlah sembilan orang yang terdiri dari komisioner, staf KPU yang mengurusi program Relawan Demokrasi, dan Relawan Demokrasi basis perempuan. Teknik pengujian keabsahan data menggunakan triangulasi sumber data. Temuan penelitian menunjukkan bahwa dalam melaksanakan tugasnya sebagai fasilitator pendidikan pemilih, 
Relawan Demokrasi mengalami beberapa kendala di antaranya (1) keterbatasan waktu masa kerja Relawan Demokrasi; waktu yang diberikan selama kurang lebih dua bulan menyebabkan tidak semua daerah bisa dikunjungi dalam memberikan informasi kepemiluan dan demokrasi; (2) keterbatasan waktu pelaksanaan kegiatan pendidikan pemilih dalam komunitas; (3) keterbatasan pengetahuan Relawan Demokrasi mengenai teknis kepemiluan serta minimnya kepercayaan diri dalam menyampaikan materi kepada komunitas sehingga dari internal relawan hanya orang tertentu yang diandalkan sebagai narasumber, sementara yang lainnya hanya bertugas memfasilitasi kegiatan seperti pembagian camilan, pemasangan spanduk/banner dan mempersiapkan presensi; (4) apatisme komunitas sasaran terhadap informasi kepemiluan sehingga menyulitkan pemberian pemahaman bahkan motivasi untuk ikut berpartisipasi dalam pemilu. Relawan Demokrasi sebagai partner KPU mengajak masyarakat untuk menjadi pemilih cerdas dan bertanggung jawab guna mewujudkan pemilu yang berkualitas.

Kata Kunci: Relawan Demokrasi, pemilih perempuan, pendidikan pemilih

This work is licensed under the Creative Commons Attribution-ShareAlike 4.0 International License. (2021 by the author(s).

\section{PENDAHULUAN}

Relawan Demokrasi, selanjutnya disebut Relasi, merupakan sebuah program yang dirancang oleh Komisi Pemilihan Umum (KPU) RI guna meningkatkan partisipasi politik warga negara. Relawan direkrut dari berbagai kelompok masyarakat yang kemudian disegmentasi sesuai dengan komunitasnya sehingga relawan memberikan informasi kepemiluan dan demokrasi sesuai dengan segmentasi kelompoknya. Program Relasi pertama kali dilaksanakan pada pemilu nasional 2014. Program ini dilatarbelakangi oleh rendahnya angka partisipasi politik pemilih. Angka partisipasi pada empat pemilu nasional terakhir yakni 92\% (1999), 84\% (2004), 71\% (2009), dan 73\% (2014). Terdapat beberapa faktor penyebab turunnya angka partisipasi, di antaranya ketidakpuasan atas kinerja sistem politik yang tidak memberikan perbaikan kualitas hidup dan melemahnya kesadaraan masyarakat tentang pentingnya pemilu sebagai instrumen transformasi sosial (KPU, 2019).

Program relasi merupakan bagian dari pendidikan pemilih kepada masyarakat guna menyadari pentingnya pemilu, mengajak masyarakat untuk menjadi pemilih cerdas dan bertanggung jawab sehingga tidak menjadi obyek politik uang dan hoaks politik serta memahami proses penyelenggaraan pemilu sehingga mampu mengawasi pemilu guna meningkatkan kualitas demokrasi. Masyarakat yang paham, sadar, peduli, dan berpartisipasi aktif dalam proses demokrasi seperti pemilu merupakan prasyarat untuk membangun budaya politik partisipan. Demokrasi Pancasila hanya akan mewujud dalam budaya masyarakat yang partisipan. Masyarakat yang apatis dan pasif dalam proses demokrasi hanya akan melemahkan dan memperburuk demokrasi itu sendiri. Sistem politik demokrasi hanya akan dinikmati oleh para penguasa dan pemilik modal untuk mempertahankan kekuasaan dan menarik keuntungan. Artinya, partisipasi politik tidak cukup hanya dengan datang ke TPS dan memberikan suara, namun juga harus 
memperhatikan hal-hal berikut (1) memastikan cara pencoblosan yang benar saat memberikan suara supaya suara tidak terbuang sia-sia karena tidak sah akibat kesalahan teknis pencoblosan; (2) menentukan pilihan politik secara rasional artinya melihat dan memahami visi, misi, program, dan rekam jejak kandidat. Berdasarkan itulah, pilihan politik ditentukan bukan karena iming-iming politik uang, tertipu hoaks politik atau karena alasan tradisional lainnya seperti ikatan keluarga atau tetangga dengan kandidat, berdasarkan karisma atau melihat keturunan. Program Relasi hadir untuk memberikan pendidikan pemilih kepada masyarakat guna memastikan hal tersebut hadir di tengah masyarakat. Program Relasi memiliki 10 segmen yang akan menjadi sasaran pendidikan pemilih; pemilih perempuan satu di antaranya. Relasi memiliki peran positif dalam meningkatkan partisipasi masyarakat dalam semua segmen (Fuad, 2015).

Pendidikan pemilih yang dilakukan oleh Relasi kepada basis pemilih perempuan dipandang strategis mengingat beberapa hal yakni (1) Relasi merupakan program nasional sehingga daya jangkauannya bersifat luas dan masif dalam menyampaikan informasi kepemiluan dan demokrasi. Semakin luas informasi yang disampaikan semakin banyak pemilih perempuan yang teredukasi secara politik; (2) Relasi merupakan sebuah gerakan kesukarelaan dari pemilih untuk pemilih, dengan mengedukasi sesama (dalam komunitasnya) mengenai konsep kepemiluan dan demokrasi, diharapkan informasi kepemiluan akan tersampaikan dengan baik melalui bahasa yang mudah dimengerti dan dipahami masyarakat/komunitasnya; (3) terdapat banyak perkumpulan perempuan di masyarakat baik yang bersifat formal seperti organisasi perempuan PKK dan Dharma Wanita maupun yang tidak formal seperti arisan dan yasinan/pengajian. Relasi dapat berasal dari kelompokkelompok tersebut sehingga informasi kepemiluan dan demokrasi yang disampaikan dapat dicerna dengan baik dalam nuansa santai. Jika dilihat secara kuantitatif, angka partisipasi politik perempuan cukup tinggi dalam beberapa pemilu, seperti yang terjadi di Provinsi Riau pada pemilu 2019 (https://riaupos.jawapos.com/5677/opini/23/10/2019/potret-partisipasi-pemilihriau-.html). Partisipasi politik perempuan menarik untuk dikaji karena perempuan memiliki peran strategis dalam keluarga, organisasi perempuan, masyarakat sekitarnya maupun di lingkungan/tempat ia bekerja jika sebagai wanita karir (Hariyanti, 2018; Maheswari, 2019). Relasi basis pemilih perempuan mempunyai tantangan dan kendala tersendiri. Artikel ini akan mengeksplorasi kendala-kendala yang dihadapi Relasi dalam melakukan pendidikan pemilih kepada pemilih perempuan di Kota Pekanbaru dan Kota Dumai.

\section{METODE PENELITIAN}

Penelitian ini menggunakan pendekatan kualitatif dengan metode deskriptif. Penelitian dilakukan pada Relawan Demokrasi basis pemilih perempuan di Kota Pekanbaru dan Kota Dumai. Kedua kota tersebut dipilih karena berdasarkan urutan partisipasi politik dalam pemilu 2019, Kota Pekanbaru menempati posisi tertinggi di Provinsi Riau yakni sekitar 93,97\%, sementara Kota Dumai, yang tergabung dengan Bengkalis dan Meranti dalam dapil Riau 5 menempati posisi keenam dengan angka partisipasi $82,40 \%$. Penelitian ini bermaksud untuk mendeskrispikan kendala- 
kendala yang dihadapi oleh Relawan Demokrasi basis perempuan guna meningkatkan partisipasi politik pemilih perempuan. Penelitian dilaksanakan dalam rentang waktu bulan Juni-November 2020. Penentuan informan penelitian dilakukan melalui teknik non probability sampling dengan teknik purposive sampling. Informan yang diwawancarai secara mendalam sebanyak sembilan orang. Informan penelitian terdiri dari komisioner KPU, staf KPU yang mengurusi pelaksanaan program Relawan Demokrasi, dan anggota Relawan Demokrasi basis perempuan. Pengumpulan data dilakukan melalui teknik wawancara dan studi dokumentasi. Analisis data menggunakan model Miles dan Huberman meliputi langkah reduksi data, penyajian data dan penarikan kesimpulan serta verifikasi. Dalam penelitian ini, peneliti menggunakan triangulasi sumber. Triangulasi sumber untuk menguji kredibilitas data dilakukan dengan cara mengecek data yang telah diperoleh melalui beberapa sumber. Selain itu, peneliti juga menggunakan triangulasi teknik pengumpulan data dengan cara mengecek data yang telah diperoleh melalui beberapa teknik pengumpulan data yang digunakan yakni wawancara dan dokumentasi. Setelah dianalisis, data dideskripsikan dan dikategorisasikan berdasarkan persamaan, perbedaan, dan spesifikasi dari beberapa sumber data tersebut. Data yang telah dianalisis tersebut akan menghasilkan suatu kesimpulan yang selanjutnya akan dimintakan kesepakatan (member check) dengan beberapa sumber data tersebut (Sugiyono, 2013).

\section{HASIL PENELITIAN DAN PEMBAHASAN}

Pendidikan pemilih merupakan usaha untuk menanamkan nilai-nilai yang berkaitan dengan pemilu dan demokrasi dalam kehidupan berbangsa dan bernegara kepada warga negara yang telah memenuhi syarat sebagai pemilih dalam pemilu atau potensial pemilih dalam rentang waktu kemudian. Pendidikan pemilih memiliki tujuan sebagai berikut: (1) meningkatkan partisipasi politik warga negara; (2) meningkatkan literasi politik; dan (3) meningkatkan sikap kerelawanan pemilih (Manik \& Budhiati, 2015). Guna mencapai tujuan tersebut, terdapat beberapa strategi pendidikan pemilih salah satunya melalui Program Relawan Demokrasi (Relasi).

Relasi merupakan program yang dirancang oleh KPU RI dalam menghadapi pemilu guna meningkatkan partisipasi politik warga negara oleh pemilih (Relasi) untuk pemilih (masyarakat), sebab relawan yang direkrut berasal dari kelompok pemilih berdasarkan segmentasi berbagai komunitas yang ada di masyarakat untuk memberikan informasi kepemiluan dan demokrasi. Pemilih perempuan merupakan satu di antara segmen tersebut. Pemilih perempuan perlu segera mendapatkan pendidikan pemilih karena beberapa pertimbangan, yakni; (1) masih adanya dikotomi antara perempuan dan politik. Politik dipersepsikan sebagai aktivitas yang kejam, jahat, penuh persaingan, penuh intrik dan tidak cocok dengan karakteristik kaum perempuan yang digambarkan sebagai pribadi yang lemah lembut, menghindari konflik dan tidak teguh memegang prinsip (Novianti, 2008; Predescu \& Darjan, 2010; Zamroni, 2013). Persepsi ini seringkali membuat perempuan menarik diri dari hal-hal yang berbau politik termasuk memberikan suara dalam pemilu; (2) kaum perempuan masih dilihat sebagai objek dalam dunia politik. Kebanyakan pemilih perempuan dikenal sebagai pemilih loyal dan sangat subyektif 
sehingga seringkali menjadi objek sasaran kontestan pemilu yang bersifat pragmatis (Mubyarto, 2014). Menimbang hal tersebut diatas, Relasi hadir untuk memberikan pendidikan pemilih bagi kaum perempuan. Namun, dalam pelaksanaannya terdapat beberapa kendala yang dapat dikelompokkan menjadi kendala internal dan kendala eksternal.

Adapun kendala internal yang ditemui diantaranya, pertama, keterbatasan waktu masa kerja relasi. Relasi dihadirkan untuk mengedukasi masyarakat seputar informasi kepemiluan, tujuannya untuk meningkatkan partisipasi dan kualitas pemilu, sehingga pelaksanaan program ini dilakukan sebelum pelaksanaan pemilu. Pelaksanaan pemilu serentak tahun 2019 dilaksanakan pada tanggal 17 April 2019. Dalam surat KPU No.32/PP.08-SD/06/KPU/5/2019 tentang pembekalan Relawan Demokrasi pemilu serentak tahun 2019 kepada ketua KPU/KIP Kabupaten/Kota, dinyatakan beberapa poin sebagai berikut (1) KPU/KIP kabupaten/kota diminta agar membentuk Relawan Demokrasi paling lambat tanggal 17 Januari 2019; (2) Anggaran pembentukan Relawan Demokrasi dibebankan kepada DIPA KPU pada mata anggaran pendidikan pemilih; (3) pelaporan pembentukan Relawan Demokrasi disampaikan kepada KPU pada 31 Januari 2019. Dalam Juknis Relasi tahun 2019 ditentukan bahwa Relasi mulai turun ke lapangan pada minggu keempat bulan Januari 2019 hingga minggu kedua di bulan April 2019. Artinya, masa kerja Relasi selama 14 minggu. Relasi direkrut dari masyarakat umum, sebelum mendaftar menjadi relawan, mereka rata-rata telah memiliki pekerjaan sehingga menjadi relawan dijadikan sebagai pekerjaan sampingan.

Hasil wawancara dengan para informan penelitian menunjukkan bahwa ratarata yang menjadi Relasi basis perempuan adalah guru, mahasiswa, dan ibu rumah tangga. Mereka menyatakan bahwa cukup dipusingkan dengan masa kerja yang relatif pendek dengan wilayah kerja yang cukup luas. Wilayah kerja Relasi adalah kota dari domisili relawan yang bersangkutan. Satu kota terdiri dari beberapa kecamatan. Umumnya, Komunitas pemilih perempuan yang menjadi sasaran pendidikan pemilih adalah wirid/pengajian, arisan RT/RW, kelompok senam, dan dharmawanita/dasawisma. Pada awal masa kerja, Relasi memang telah menyusun program dan jadwal namun ketika turun ke lapangan seringkali jadwal yang disusun tidak bisa terlaksana karena adanya ketidakcocokan jadwal dengan pertemuan komunitas sasaran. Jika dilakukan pertemuan di luar jadwal rutinan komunitas maka anggota yang hadir tidak banyak, artinya di sini relawan mencoba memanfaatkan momen perkumpulan komunitas ibu-ibu untuk melaksanakn pendidikan pemilih. Kendala masa kerja yang pendek memberikan dampak tersendiri di antaranya: (1) tidak semua kecamatan terdatangi untuk melaksanakan pendidikan pemilih kepada komunitas pemilih perempuan, contohnya di daerahdaerah perbatasan yang jauh dari pusat kota; (2) KPU menargetkan minimal tiga kegiatan setiap bulannya sehingga Relasi umumnya mencari komunitas pemilih perempuan yang mempunyai kecocokan jadwal dengan mereka sehingga terdapat beberapa daerah yang sering menjadi sasaran Relasi sementara ada daerah lain yang belum terdatangi. 
Komunitas sasaran kelompok pengajian menjadi sasaran yang sering didatangi dalam beberapa wilayah kecamatan baik di Kota Pekanbaru maupun di Kota Dumai. Relasi memandang bahwa komunitas ini cukup efektif dan efisien untuk didatangi sebab telah memiliki jadwal yang relatif tetap setiap bulannya, anggota yang hadir relatif banyak dalam setiap pertemuannya, gaya berkomunikasi yang lebih terbuka serta kemudahan akses koordinasi dengan pengurus sasaran. Potensi lokal bisa dikembangkan untuk membantu pemerintah dalam membangun bangsa Indonesia, salah satunya kelompok pengajian ibu-ibu yang tersebar di seluruh pelosok tanah air. Kelompok ini memiliki modal sosial yang dapat dimanfaatkan untuk mensukseskan kegiatan kepemiluan (Neila \& Hidayat, 2017). Perempuan yang tergabung dalam kelompok pengajian berasal dari beragam kalangan dan profesi, sehingga jika mereka dapat teredukasi secara politik dengan baik maka mereka dapat menjadi agen sosialisasi politik setidaknya untuk lingkungan keluarganya seperti mengajak untuk memberikan hak pilih dan tidak tertipu hoax politic maupun money politic. Nah, untuk mewujudkan tujuan-tujuan tersebut tentunya Relasi membutuhkan waktu/masa kerja tidak sebentar. Ketergesaan untuk sekedar memenuhi target sosialisasi yang ditetapkan penyelanggara membuat kinerja Relasi relatif tidak efektif.

Kendala kedua yakni keterbatasan waktu pelaksanaan kegiatan pendidikan pemilih pada komunitas sasaran. Juknis Relasi tidak menentukan berapa lama waktu pelaksanaan pendidikan pemilih. Temuan penelitian menunjukkan bahwa rata-rata Relasi melaksanakan pendidikan pemilih selama kurang lebih 20 menit, hal tersebut sudah masuk dengan tanya jawab seputar pemilu. Kegiatan pendidikan pemilih oleh Relasi rata-rata mengikuti kegiatan rutin komunitas perempuan yang sudah terjadwal, artinya tidak membuat kegiatan sendiri sehingga agenda pendidikan pemilih bukan agenda utama. Waktu pelaksanaan pendidikan pemilih yang terbatas menyebabkan beberapa hal yaitu: (1) materi kepemiluan yang ada dalam juknis Relasi tidak dapat disampaikan semuanya; (2) metode yang umumnya digunakan adalah ceramah ditambah dengan membawa alat peraga berupa surat suara untuk pengenalan contoh surat suara pemilu serentak tahun 2019 kepada pemilih perempuan; padahal terdapat banyak metode menarik yang dapat digunakan untuk meningkatkan antusiasme sekaligus pemahaman pemilih perempuan seperti Simulasi, Bermain peran/role playing maupun FGD (KPU, 2019); (3) peserta pendidikan pemilih tidak leluasa bertanya seputar kepemiluan karena waktu yang terbatas. Pemberian materi dari Relasi bahkan dengan adanya fasilitasi narasumber merupakan kesempatan yang baik bagi pemilih perempuan untuk mendapatkan informasi yang lengkap dan jelas seputar kepemiluan dan demokrasi. Justru kekurangan informasilah yang menjadi penyebab masih rendahnya partisipasi politik perempuan padahal mereka memiliki minat memilih (Sarinastiti \& Fatimah, 2019). Perempuan dikategorikan sebagai pemilih loyal dan memiliki jumlah yang besar dalam setiap pemilu sehingga rentan dimobilisasi oleh peserta pemilu untuk mendulang suara dengan beragam cara seperti melalui pembagian sembako, pembagian baju/jilbab, diajak bertamasya ke tempat-tempat wisata, juga melalui pelabelan emak-emak atau ibu bangsa guna terkesan akrab dengan sasaran (Amalia, 
2019). Guna mengantisipasi hal tersebut dibutuhkan pendidikan pemilih dengan materi yang jelas dan lengkap melalui metode yang mudah dipahami oleh perempuan serta rentang waktu diskusi yang relatif lama antara narasumber dengan sasaran sehingga tujuan pendidikan pemilih dapat tersampaikan.

Kendala ketiga yaitu keterbatasan pengetahuan Relasi mengenai teknis kepemiluan. Juknis Relawan Demokrasi 2019 menentukan bahwa materi pembekalan yang diberikan kepada Relasi adalah pentingnya demokrasi, pemilu dan partisipasi, pemahaman tentang teknis tahapan pemilu yang strategis, kode etik relawan, teknik-teknik berkomunikasi publik dan materi lain yang relevan. Pendaftaran Relasi dibuka untuk umum sehingga mereka dapat berasal dari kalangan dan profesi apapun. Dalam Juknis tersebut juga diatur mengenai persyaratan warga negara yang dapat mendaftar pada program Relasi, di antaranya memiliki komitmen menjadi relawan pemilu, memiliki kemampuan berkomunikasi yang baik, bertanggung jawab dan berakhlak baik, memiliki pengalaman dalam kegiatan penyuluhan atau aktif dalam organisasi kemasyarakatan/kemahasiswaan, membuat program kerja yang akan dilaksanakan, serta bagi peserta yang pernah mengikuti kegiatan KPU (Kursus Kepemiluan/Jambore Demokrasi/KPU Goes to Campus/School/Pesantren) memperoleh prioritas.

Temuan penelitian menunjukkan bahwa Relasi basis perempuan Kota Pekanbaru dan Kota Dumai yang berpengalaman dan aktif dalam kegiatan kepemiluan hanya dua orang karena pernah menjadi anggota PPS serta menjadi kader posyandu, kader PKK dan kader kampung Keluarga Berencana di lingkungannya. Ketika memberikan pendidikan pemilih kepada komunitas perempuan, materi yang paling banyak dipertanyakan adalah masalah teknis kepemiluan. Menurut penuturan salah satu informan penelitian, Relasi cukup sering mengundang komisioner sebagai narasumber sebab masyarakat umumnya mempertanyakan hal-hal teknis kepemiluan, di mana Relasi relatif kurang bisa menjelaskan secara gamblang karena keterbatasan pengetahuan. Hal tersebut setidaknya disebabkan oleh beberapa hal yaitu (1) Relasi umumnya tidak berasal dari pegiat pemilu seperti mantan anggota KPPS, PPS, PPK atau organisasi pemantau pemilu lainnya; (2) pembekalan/pelatihan Relasi umumnya hanya diberikan sekali atau dua kali. Pembekalan Relasi umumnya hanya menyentuh tataran materi baku kepemiluan sehingga abai dengan persoalan teknis yang justru ingin diketahui oleh masyarakat; (3) kurangnya pemahaman beberapa anggota Relasi terhadap basis segmen yang diedukasinya; (4) minimnya kepercayaan diri dalam menyampaikan materi kepada komunitas.

Temuan penelitian menunjukkan bahwa dari kalangan Relasi sendiri hanya beberapa orang tertentu saja yang diandalkan sebagai narasumber, sementara yang lainnya hanya bertugas memfasilitasi kegiatan seperti membagikan camilan, memasang spanduk/banner dan mempersiapkan absensi. Menurut penuturan salah seorang Relasi yang biasa menjadi narasumber kegiatan, hal tersebut terjadi karena mereka sudah merasa ada yang layak dan diandalkan sehingga yang lain tidak bersedia menjadi narasumber. Hal serupa juga terjadi pada Relawan Demokrasi Aceh bahwa kendala yang dihadapi saat sosialisasi umumnya adalah gaya bahasa, 
teknik, waktu, dan mental anggota Relasi (Hariadi, 2015). Relasi merupakan relawan yang mendaftarkan diri dalam kerja-kerja demokrasi, artinya disini sekurangkurangnya mereka memiliki niat dan iktikad baik untuk terjun dalam mengedukasi masyarakat terlepas dari keterbatasan pengetahuan yang dimiliki. Oleh karena itu, tentu saja perlu fasilitasi dan pembekalan yang baik sehingga mereka dapat menjadi komunikator politik yang efektif bagi komunitasnya. (Susilatuti, Soeprapto, 2015). Kendala ini harus segera diatasi sebab Relasi merupakan agen strategis dalam penyampaian informasi kepemiluan.

Kendala keempat yakni apatisme komunitas sasaran terhadap informasi kepemiluan sehingga cukup menyulitkan dalam memberikan pemahaman bahkan motivasi untuk ikut berpartisipasi dalam pemilihan umum. Partisipasi politik perempuan dalam politik masih rendah sebab pendidikan politik terhadap perempuan belum cukup untuk membuka kesadaran politik (Destemi, 2020). Selain itu, faktor penyebab lainnya ialah (1) jenuh dengan proses pemilu yang berkepanjangan; (2) tidak puas dengan kinerja system politik; (3) perempuan sering menjadi obyek dan sasaran kandidat selama masa kampanye, setelah kandidat terpilih, pemilih kaum perempuan dilupakan sehingga menimbulkan kesan dan pengalaman yang tidak enak yang berulang-ulang di masa-masa memasuki pemilihan umum. Relasi perlu berinovasi untuk menerapkan strategi guna menarik minat pemilih perempuan seperti yang diterapkan Relasi Magelang pada pilkada 2015 dimana mereka menerapkan strategi ofensif seperti menjalin kerjasama dengan organisasi perempuan ataupun melalui kegiatan-kegiatan yang familiar dan sesuai dengan aktivitas target/perempuan (Wibowo, et.al., 2019) ataupun melalui penggunaan media sosial yang telah terbukti bermanfaat dalam sosialisasi pemilu seperti pada pilkada Surabaya tahun 2018 (Ms, 2018). Pendidikan politik virtual dapat menjadi solusi apalagi di masa pandemi di mana kegiatan dan aktivitas sosial tatap muka relatif dibatasi.

Upaya-upaya yang dapat dilakukan guna mengatasi kendala yang dihadapi Relasi basis perempuan di antaranya perpanjangan masa kerja Relasi selanjutnya dapat diatur melalui Peraturan Komisi Pemilihan Umum, kreativitas dan inisiatif Relasi untuk melaksanakan kegiatan pendidikan pemilih dengan membuat kegiatan atau acara yang menarik minat dan antusiasme pemilih perempuan, pemberian pelatihan/pembekalan secara berkala pada masing-masing basis oleh salah satu komisioner yang telah dibagi sebelumnya mengenai tanggung jawab basisnya. Artinya, pelatihan dapat dilakukan secara formal, seperti melalui diskusi santai atau via sambungan telepon (jika komisioner sibuk dengan tahapan pemilu) mengenai materi teknis kepemiluan yang kurang dipahami Relawan Demokrasi. Upaya-upaya peningkatan keterampilan akademis maupun teknis kepada para Relasi urgent dilakukan sebab mereka merupakan corong informasi kepemiluan bagi komunitasnya. Informasi yang diberikan inilah yang akan dicerna dan dieksekusi oleh pemilih perempuan.

Sedangkan upaya-upaya yang dapat dilakukan guna mendorong partisipasi perempuan seperti dari sisi regulasi, di mana pemerintah telah mengeluarkan peraturan affirmative action untuk memperkuat dan mendorong kedudukan serta 
keterwakilan perempuan dalam politik dengan kebijakan kuota minimal 30\% pada pencalonan kandidat legislatif oleh partai politik, kewajiban partai politik dalam memberikan pendidikan politik pada kader termasuk kader perempuan, dan kebijakan kuota yang dikeluarkan pemerintah untuk menciptakan the political of presence. Jika diikuti dengan pembekalan dari partai, kegiatan tersebut diharapkan dapat menciptakan the political of idea, artinya perempuan dapat membuat kebijakankebijakan yang dikeluarkan pemerintah berbasis pengarusutamaan gender atau permisif dengan kebutuhan perempuan (PERLUDEM, 2019). Selain itu, pendidikan pemilih kaum perempuan dapat menjadi satu strategi untuk mendukung affirmative action di mana fasilitator/Relasi memberikan edukasi seputar perempuan dan politik, pentingnya perempuan aktif dalam politik praktis, tokoh-tokoh perempuan nasional dan internasional hingga gambaran kebijakan/gebrakan yang dapat dilakukan perempuan untuk negara. Inilah yang akan direnungkan dan dieksekusi oleh pemilih perempuan terkait dengan pilihan memilih caleg perempuan sebab orientasi kognitif, orientasi afektif, dan orientasi evaluatif pemilih perempuan berpengaruh positif terhadap keputusan memilih caleg perempuan (Nularna, 2017).

Pemberian literasi politik tidak hanya dilakukan oleh pemerintah tetapi juga oleh organisasi masyarakat yang peduli perempuan seperti Koalisi Perempuan Indonesia (KPI) Jawa Timur yang melakukan kegiatan pendidikan pemantau, pendidikan pemilih maupun kursus caleg dan kegiatan kelas politik yang berkoordinasi dengan pemerintah (Novita dan Sari, 2019). Tujuannya tidak hanya sekedar memberikan pengetahuan politik tetapi untuk mendorong kaum perempuan untuk aktif berpolitik praktis secara cerdas. Selain itu juga terdapat beberapa upaya lain untuk mendorong partisipasi perempuan di antaranya (1) pendidikan dari keluarga bahwa berkiprah serta berpartisipasi di dunia politik adalah salah satu bagian yang penting untuk membangun masyarakat, bangsa dan negara; (2) anak perempuan yang mengikuti pendidikan politik sejak dasar di sekolah menengah sampai universitas didorong untuk aktif mengikuti organisasi OSIS, BEM, HIMA dan organisasi ekstra universitas seperti HMI, GMNI, KNPI, NU, dan Muhammadiyah; (3) melakukan advokasi kepada kaum perempuan supaya terpanggil untuk berpartisipasi dalam kancah politik; (4) mempersiapkan anak-anak perempuan sejak dini untuk terpanggil dan tertantang memasuki dunia politik melalui kurikulum yang berbasis pada pengenalan politik sejak dini; (5) memberi pencerahan, penyadaran, dan dorongan kepada kaum perempuan supaya aktif dalam berbagai kegiatan politik seperti kampanye, ikut mengikuti pelatihan/pendidikan politik maupun berpartisipasi dalam pemilu (Priandi \& Roisah, 2019).

\section{SIMPULAN}

Dalam melaksanakan pendidikan pemilih kepada pemilih perempuan, masih terdapat kendala yang ditemui Relawan Demokrasi, seperti kendala waktu masa kerja, kendala waktu pelaksanaan kegiatan pendidikan pemilih, kendala keterbatasan pengetahuan Relasi mengenai teknis kepemiluan hingga apatisme masyarakat seputar masalah kepemiluan dan demokrasi. Oleh karena itu, berdasarkan hasil penelitian ini disarankan hal-hal sebagai berikut: (1) perlu adanya 
masa kerja yang cukup bagi Relawan Demokrasi dalam melakukan pendidikan pemilih, yang biasanya tiga bulan menjelang pemilu dapat diubah menjadi enam bulan menjelang pemilu dengan penyesuaian anggaran dan kegiatan terhadap program ini; (2) perlu adanya pelatihan bagi para Relawan Demokrasi, tidak hanya sekedar bimbingan teknis/pembekalan sehari tetapi semacam pelatihan untuk pelatih/relawan yang tidak hanya dari segi materi yang akan disampaikan tetapi bagaimana teknik menyusun kegiatan dan mengatur waktu, public speaking hingga kemampuan dalam melakukan ice breaking.

\section{UCAPAN TERIMA KASIH}

Penulis mengucapkan terima kasih kepada Dekan Fakultas Keguruan dan Ilmu Pendidikan Universitas Riau yang telah membiayai pelaksanaan penelitian ini, serta kepada tim peneliti dan informan penelitian yang turut membantu proses penelitian sehingga tercipta artikel ini.

\section{REFERENSI}

Amalia, L. S. (2019). Upaya Mobilisasi Perempuan Melalui Narasi Simbolik 'EmakEmak dan Ibu Bangsa' Pada Pemilu 2019. Jurnal Penelitian Politik, 16 (1), 17. https://doi.org/10.14203/jpp.v16i1.779.

Destemi, S. (2020). Pendidikan politik perempuan dalam menghadapi pemilihan kepala daerah Provinsi Jambi tahun 2020. Seminar Nasional Pemberdayaan Masyarakat, Pekanbaru, 2 (ISSN 2685-9017), 11-19.

Fuad, Zam Zam Muhammad. (2015). MENINGKATKAN PARTISIPASI POLITIK MASYARAKAT PADA PEMILIHAN UMUM LEGISLATIF TAHUN 2014 DAN IMPLIKASINYA TERHADAP KETAHANAN POLITIK WILAYAH. Jurnal Ketahanan Nasional, 1, 23-33.

Hariadi, N. (2015). Analisis kinerja relawan demokrasi dalam pemilihan umum legislatif di kota banda aceh. Jurnal Pendidikan Pancasila Dan Kewarganegaraan, 2, 125-129.

Hariyanti. (2018). PERANAN PARTAI POLITIK DALAM MENINGKATKAN PARTISIPASI POLITIK KADER PEREMPUAN MELALUI PENDIDIKAN POLITIK (Studi Deskriptif pada Dewan Pimpinan Wilayah Partai NasDem Provinsi Sumatera Barat)". Universitas Pendidikan Indonesia.

KPU. (2019). Pedoman pelaksanaan Relasi pemilu tahun 2019. Komisi Pemilihan Umum Republik Indonesia.

Maheswari, S. Arum. (2019). Perilaku pemilih relawan perempuan dalam pemilihan presiden Republik Indonesia 2019 [Universitas Lampung]. In universitas lampung. https:// doi.org/10.1017/CBO9781107415324.004.

Manik, H. K., \& Budhiati, I. (2015). Pedoman pendidikan pemilih. Komisi Pemilihan Umum Republik Indonesia.

Ms, Taufiq. (2018). Sosialisasi politik virtual dalam pemilihan gubernur jawa timur 2018. Sksripsi.

Mubyarto Amin. (2014). RELASI RELAWAN DEMOKRASI DAN PEMILIH PADA PEMILU TAHUN 2014. Disampaikan pada Acara Pembekalan Peran Serta Relawan Demokrasi Dalam Usaha Meningkatkan Partisipasi Pemilih Pada 
Pemilu 2014, Penyelenggara KPU Provinsi Sumatera Utara, Di Hotel Garuda Plaza, 31 Maret 2014.

Neila \& Hidayat. (2017). Pemberdayaan Kelompok Pengajian Perempuan Berbasis Modal Sosial Di Kota Medan. Jurnal Antropologi Sumatera, 15(1), 259-269. https:/ / doi.org/10.1017/CBO9781107415324.004.

Novianti, I. (2008). Dilema kepemimpinan perempuan dalam islam. Jurnal Studi Gender Dan Anak Yin Yang, 3(2).

Novita, Anggi, Maya Mustika Kartika Sari. (2019). Orientasi Koalisi Perempuan Indonesia (KPI) Jawa Timur Melakukan Literasi Politik Guna Mendorong Penguatan Perempuan dalam Politik. Jurnal Kajian Moral dan Kewarganegaraan, 7(3), 1268-1284.

Nularna, P. (2017). Orientasi Politik Pemilih Perempuan dan keputusan memilih. Jurnal Demokrasi Dan Otonomi Daerah, 15(1), 25-30.

PERLUDEM, W. (2019). Dinamika pemenuhan kebutuhan dana kampanye calon anggota legislatif perempuan pada pemilu 2019. studi kasus: daerah pemilihan DKI Jakarta II.

Predescu, M., \& Darjan, I. (2010). Promoting political participation through adult education. Procedia - Social and Behavioral Sciences, 2(2), 3241-3245. https:// doi.org/10.1016/j.sbspro.2010.03.495.

Priandi, R., \& Roisah, K. (2019). Upaya Meningkatkan Partisipasi Politik Perempuan Dalam Pemilihan Umum di Indonesia. Jurnal Pembangunan Hukum Indonesia, 1(1), 106. https:// doi.org/10.14710/jphi.v1i1.106-116.

Sarinastiti, N., \& Fatimah, P. S. (2019). Edukasi komunikasi politik dalam menciptakan kesadaran dan minat pemilih perempuan. Jurnal Kajian Komunikasi, 7(1), 44-58. https:/ / doi.org/10.24198/jkk.v7i1.19125.

Susanto, N.N. (2019). Potret Partisipasi Pemilih Riau. Riau Pos.co, Opini. https:/ / riaupos.jawapos.com/5677/opini/23/10/2019/potret-partisipasipemilih-riau-.html (diakes pada 10 April 2020).

Susilatuti DN, Adi Soeprapto, B. A. S. (2015). Relawan Demokrasi Sebagai Komunikator Politik bagi Pemilih Pemula. Prosiding KNK ISKI, 5.

Wibowo, Eko Ari, Muradi, Arfin Sudirman. (2019). Strategi sosialisasi politik dalam peningkatan partisipasi pemilih perempuan pada pilkada serentak di kota magelang. Cosmogov: Jurnal Ilmu Pemerintahan, 05 (01), 58-70. https:// doi.org/10.24198/cosmogov.v2i2.xxxxx.

Zamroni, M. (2013). Perempuan dalam kajian komunikasi politik dan gender. Jurnal Dakwah, XIV(1), 103-132. 